\title{
Productivity and nutritive value of elephant grass pastures under organic and conventional production systems
}

\author{
GABRIELA D. SIMONETTI, CLAIR J. OLIVO, DAIANE C. SEIBT, VINICIUS \\ F. BRATZ, JULIO C. SAUTHIER and CARINE B. ADAMS
}

Departamento de Zootecnia, Universidade Federal de Santa Maria, Av. Roraima, 1000, Camobi, 97105-800 Santa Maria, RS, Brazil

Manuscript received on January 16, 2018; accepted for publication on August 29, 2018

\begin{abstract}
How to cite: SIMONETTI GD, OLIVO CJ, SEIBT DC, BRATZ VF, SAUTHIER JC AND ADAMS CB. 2019. Productivity and nutritive value of elephant grass pastures under organic and conventional production systems. An Acad Bras Cienc 91: e20180011. DOI 10.1590/0001-3765201920180011.
\end{abstract}

\begin{abstract}
Elephant grass (EG) (Pennisetum purpureum Schum.) have great importance in tropical and subtropical climates, especially on dairy farms. Normally, EG is established alone under high fertilization levels. EG in organic production system can improve low production costs and environmental issues, are still little known. The aim of this research was to evaluate the performance of herbage yield, nutritive value, extraction/ export nutrient and forage yield and animal responses. Three production systems of EG were analyzed: (i) EG mixed spontaneous-growing species (SGE) in warm-season and ryegrass (R) in cool-season under organic production; (ii) EG mixed SGE + R under conventional system (positive control); and (iii) EG based under conventional production (control). Holstein cows were used in a rotational stocking. Forage samples were collected to evaluate the pasture and animal responses. Seven grazing cycles were performed during the experimental period (312 days). Herbage yield, forage intake, and stocking rate were 12548; $10270 ; 19168 \mathrm{~kg} \mathrm{ha}^{-1}$ and 2.5; 2.6;2.7\% and 3.3; $2.1 ; 4.5 \mathrm{AU}^{-1} \mathrm{day}^{-1}$, respectively. Crude protein of EG was $17.9 ; 15.4 ; 16.4 \%$, respectively. Mixed pastures, in conventional and organic production, had a better forage distribution throughout the seasons. Highest forage yield and extraction/ export nutrient was reported in pure EG within the conventional system.
\end{abstract}

Key words: crude protein, dairy cows, Pennisetum purpureum Schum, production of forage, stocking rate.

\section{INTRODUCTION}

Milk production is one of the predominating alternatives for small- and medium- sized farms in different regions of Brazil. Pasture, the main roughage source, is comprised of grass established in monoculture and with mineral fertilizers (Olivo et al. 2006).

Correspondence to: Gabriela Descovi Simonetti

E-mail: gabidsimonetti@yahoo.com.br

ORCid: https://orcid.org/0000-0001-6973-6268
Perennial pasture, such as elephant grass (Pennisetum purpureum Schum.), are highly relevant due to their capacity in forage production and to their easy adaptation in tropical and subtropical regions, especially when used with rotational stocking (Pegoraro et al. 2009). Their establishment in spaced rows in organic or conventional system favors the inclusion of annual winter crops, such as oats and ryegrass, forming an important strategy due to the usage of the same area throughout the year (Diehl et al. 2014). 
It is important to underscore that such pasture composition, featuring perennial and annual grasses, produces a great conservation of naturally based resources.

The predominant use of elephant grass is in monoculture under conventional production system. In these conditions, the forage yield is concentrated in the summer (Seibt et al. 2018), with dependence of commercial nitrogen and involves high production costs and environmental issues. Elephant grass under organic production can more sustainable, but few studies have investigated this production system (Olivo et al. 2017). The aim of this research was to evaluate elephant grass-based pasture under organic and conventional production systems on the botanical and morphological compositions, herbage yield, nutritive value, grazing efficiency, forage intake, extraction/ export nutrient $(\mathrm{N})$ and forage yield, and stocking rate.

\section{MATERIALS AND METHODS}

The Committee for Ethics in Experiments with Animals of the Universidade Federal de Santa Maria, Santa Maria, RS, Brazil (Protocol 23081016073/2011-27, Process 113/2011) approved all techniques and procedures employed in current analysis.

The study was performed in Laboratory of Dairy Cattle of the Department of Animal Science of the Universidade Federal de Santa Maria (UFSM), Santa Maria, Brazil, of between May 2015 and April 2016, with a total of 312 days. The soil is classified as Hapludalf Paleudult (Smith 2014) and region's climate is $\mathrm{Cfa}$ (humid subtropical climate), following Köppen's classification (Kuinchtner and Buriol 2001). The 30-yr average annual rainfall and monthly temperature were $140.5 \mathrm{~mm}$ and 19.6 C, respectively. The experimental period was from May 2015 to April 2016 the average monthly precipitation and daily temperature were $172.7 \mathrm{~mm}$ and 20.0 C, respectively (INMET 2016).
A 0.8 ha area, subdivided into nine paddocks, was used for the study, featuring three forage systems (treatments), with elephant grass, cv. Merckeron Pinda. The organic production system was comprised of pasture with mixed forages. Elephant grass-based was planted in rows, $3 \mathrm{~m}$ apart. Ryegrass (Lolium multiflorum Lam.), cv. Ponteio, was sown in May between elephant grass rows at $40 \mathrm{~kg} \mathrm{ha}^{-1}$ during the winter; and spontaneous-growing species developed during the warm-season. Two systems were evaluated in conventional production: (1) a mixed system with the same species and the establishment of an organic production system (control); (2) a system with elephant grass was cultivated alone. In the three systems, elephant grass was mowed to a 20cm stubble, in August 2015. In systems with mixed forages, within the in-between rows, two harvests were undertaken close to the ground, in May and December 2015.

Basic fertilization was applied, following soil analysis and based on the recommendation obtained in the Comissão de Química e Fertlidade do Solo RS/SC (2004), based on recommendation for perennial grasses, with $60 \mathrm{~kg} \mathrm{P}_{2} \mathrm{O}_{5} \mathrm{ha}^{-1} \mathrm{yr}^{-1}$ and $60 \mathrm{~kg} \mathrm{ha}^{-1} \mathrm{yr}^{-1} .100 \mathrm{~kg} \mathrm{~N} \mathrm{ha}^{-1} \mathrm{yr}^{-1}$ was employed for all systems. For organic production, fertilization comprised cattle manure $\left(23.8 \mathrm{~m}^{3} \mathrm{ha}^{-1} ; 36 \% \mathrm{DM}\right)$ and swine slurry $\left(41 \mathrm{~m}^{3} \mathrm{ha}^{-1} ; 5 \% \mathrm{DM}\right)$, distributed into three applications (July, November, February). DM-based chemical composition of cattle manure and swine slurry respectively comprised 0.63 ; $1.44 ; 0.41 \%$ and $0.25 ; 0.31 ; 0.076 \%$ of $\mathrm{N}, \mathrm{P}_{2} \mathrm{O}_{5}$ and $\mathrm{K}_{2} \mathrm{O}$. To conventional production system, basic fertilization contained mineral fertilizers; urea was distributed in four applications (October, November, December and February) for nitrogen fertilization.

In the case of forage mixture systems, the height of ryegrass at $20-\mathrm{cm}$ was the criterion for the start of grazing during the cool-season; in the summer, canopy height of elephant grass had to be between 
100 and $110 \mathrm{~cm}$ (Voltolini et al. 2010). The same criterion was employed in the conventional system (elephant grass in monoculture). Grazing method consisted of rotational stocking with one-day occupation. Before and after each grazing event, the paddocks were sampled to determine pre-and post-grazing herbage mass using a double sampling technique, with five cuts close to the ground and 20 visual estimates. The above procedure was undertaken within the alignment formed by elephant grass tufts and within the in-between rows. Elephant grass, cut $50-\mathrm{cm}$ stubble height ( $1 \mathrm{~m}$ linear), plus the width of the tufts, revealed a $30.7 \%$ occupied area in mixed pastures. Between elephant grass rows $0.25-\mathrm{m}^{2}$ quadrats were used. In the paddocks of elephant grass established alone $1.0-\mathrm{m}^{2}$ were used for sampling.

Forage from the cut samples per paddock was homogenized and a sub-sample was retrieved to determine the botanic composition of the pasture and the structural composition of the elephant grass. Later were oven dried with forced air circulation at $55{ }^{\circ} \mathrm{C}$ for 72 hours to determine dry matter rates (Silva and Queiroz 2006). Mean data of pastures were grouped according to the season.

The stocking density of one-day occupation was calculated based on the herbage allowance of $4 \mathrm{~kg}$ DM per $100 \mathrm{~kg}$ BW for biomass of leaf blades of elephant grass and $10 \mathrm{~kg}$ of DM per 100 $\mathrm{kg} \mathrm{BW}$ for mass in the in-between rows of the two systems made up of forage mixtures and based on pre-grazing forage mass. Holstein lactating cows, $522 \mathrm{~kg} \mathrm{LW}$ and $17.3 \mathrm{~kg}$ milk day ${ }^{-1}$, were used. Feed supplementation, based on corn, soybean meal, rice meal, wheat meal and premix mineral, was provided at $0.9 \% \mathrm{BW}$. When the animals were not in the experimental areas, they were maintained under a similar management on seasonal pasture.

Grazing efficiency was calculated as the ratio between the amount of forage removed by the difference to pre- and post-grazing forage mass (Hodgson 1979). Herbage accumulation in the first grazing cycle was assumed as the pre-grazing forage mass. For subsequent grazing cycles, forage accumulation was calculated by subtracting the pre-grazing forage mass of the following cycle from the post-grazing forage mass of the previous cycle. The herbage accumulation rate was obtained from the relation between the herbage yield and number of days between grazing cycles. Forage yield was estimated by adding daily herbage accumulation. Stocking rate was calculated by dividing stocking density by the number of days of the grazing cycle, and by $450 \mathrm{~kg}$ to calculate animal unit (AU). Apparent forage intake was estimated by the agronomic difference (Burns et al. 1994) where the difference between forage masses (pre- and post-grazing) was divided by stocking density and multiplied by 100 .

Elephant grass and of other species in the in-between elephant grass rows were sampled to estimate nutritive value, using hand-plucked technique (Euclides et al. 1992). This occurred after observing the animals' ingestion behavior during $15 \mathrm{~min}$, at the start and end of each grazing period. Samples were dried in a forced-air buffer at $55{ }^{\circ} \mathrm{C}$ during 72 hours and stored for the later formation of compounded samples. Samples from each grazing cycle, retrieved at the beginning and end at the grazing, were mixed. Grazing samples were later mixed according to the seasons. Compounded samples were analyzed by the Laboratory of Animal Nutrition/ Federal University of Santa Maria (LABRUMEN/ UFSM) with regard to crude protein (CP) by Kjeldahl method (AOAC 1995) and in situ digestibility of the organic matter (ISDOM) (Mehrez and Orskov 1977). Total digestible nutrients (TDN) were estimated by the product of organic matter (\%) and ISDOM, divided by 100 (Barber et al. 1984). Extraction/ export dry matter rate was calculated by multiplied forage yield by grazing efficiency. Extraction/ export of $\mathrm{CP}$ as the product of forage yield by $\mathrm{CP}$ tenor. Extraction/ export $\mathrm{N}$ was calculated by dividing $\mathrm{CP}$ yield by 
6.25. The Extraction/ export of TDN was estimated by multiplied forage yield by TDN rate.

Spittlebugs (Deois flavopicta) were detected in September 2015, controlled by METARRIL $\AA$, a biological pesticide with spore of fungus Metarhizium anisopliae as its active ingredients.

Statistical analysis comprised mean data of grazing cycles in each season. Experimental design was completely randomized with three treatments (forage systems), three replications of the area (paddocks), with repeated measurement over time (seasons). The seasons' mean data underwent analysis of variance. When there was a significant interaction effect between forage system and season, means were compared by Student's t test at $5 \%$ probability, by MIXED procedure. When no interaction existed, the significant effect of the forage system was tested. Covariance matrix was chosen by the lowest AIC (Akaike's Information Criteria) rate, with Variance Components (SAS 2016). Pearson's correlation coefficient analysis was performed so that the association between variables could be verified. The statistical model used was: $\mathrm{Y}_{\mathrm{ijk}}=\mathrm{m}+\mathrm{F}_{\mathrm{i}}+\mathrm{R}_{\mathrm{j}}\left(\mathrm{F}_{\mathrm{i}}\right)+\mathrm{S}_{\mathrm{k}}+(\mathrm{FS})_{\mathrm{ik}}+\varepsilon_{\mathrm{ijk}}$, where $Y_{i j k}$ represents dependent variables; $m$ is the mean of all data; $F_{i}$ is the effect of the forage system; $R_{j}\left(F_{i}\right)$ is the effect of replication (paddocks) within the forage system (error a); $S_{k}$ is the effect of the season; $(\mathrm{FS})_{\mathrm{ik}}$ is the interaction between the forage system and the season; $\varepsilon_{\mathrm{ijk}}$ is the residual effect (error b).

\section{RESULTS AND DISCUSSION}

Seven grazing cycles (one, two, three and one, during winter, spring, summer and autumn, respectively) were conducted during the experimental 312 days. Grazing cycles had a mean 27 days each when the period of greatest development of elephant grass is taken into account, between spring and autumn. Short grazed and rest periods (approximately 30 days) on elephant grass pasture are associated with the best forage quality (Soares et al. 2004) and to the performance of lactating cows (Deresz 2001).

To pre-grazing herbage mass (Table I) grazing during the winter revealed similarity between organic and conventional pastures made up of elephant grass alone. Results were due to favorable meteorological conditions throughout the season, with high participation of elephant grass in pasture composition. The highest rate $(\mathrm{p} \leq 0.05)$, detected in mixed pasture with organic production system, may be associated with the employment of organic manure which resets micronutrients, organic matter, $\mathrm{N}, \mathrm{P}_{2} \mathrm{O}_{5}$ and $\mathrm{K}_{2} \mathrm{O}$ and improves soil fertility (Menezes et al. 2004). High response of elephant grass to organic manure is also added (Oliveira et al. 2011). There was no difference in the participation of the other botanic components of pasture when the two mixed systems (organic and conventional) were compared.

Pre-grazing herbage mass was greater $(\mathrm{p} \leq 0.05)$ in organic production pasture during spring. This was especially due to a greater participation of ryegrass, probably due to a better response in mineral fertilization. In fact, during spring, the great participation of other grasses of the summer cycle could be underscored in mixed systems, mainly Paspalum conjugatum, Cynodon dactylon, Paspalum urvillei Steud., Setaria spp. and Dichanthelium spp. The high contribution of dead material in the forage mass during spring was due to the effect of frosts and the maturation of ryegrass.

Pre-grazing elephant grass herbage mass was greater $(p \leq 0.05)$ during the summer within the conventional production system, with elephant grass cultivated alone. This occurred due to the area occupied and the highest yield of elephant grass cultivated alone, when compared to the species of spontaneous-growth present in the in-between rows of the other systems (Diehl et al. 2013).

When the mixed pastures were compared, there was a better response in the autumn with 
TABLE I

Pre-grazing herbage mass and botanic composition of pastures in three forage systems (FS). Santa Maria, Brazil, $2015-2016$.

\begin{tabular}{|c|c|c|c|c|c|c|}
\hline \multirow{2}{*}{ FS } & \multicolumn{4}{|c|}{ Season } & \multirow{2}{*}{ Mean } & \multirow{2}{*}{ CV $(\%)$} \\
\hline & Winter & Spring & Summer & Autumn & & \\
\hline \multicolumn{7}{|c|}{ Pasture forage mass $(\mathrm{kg} \mathrm{DM} \mathrm{ha-1})$} \\
\hline $\operatorname{Org}^{1}$ & $2714^{\mathrm{a}}$ & $2776^{\mathrm{a}}$ & $3879^{\mathrm{b}}$ & $3374^{\mathrm{a}}$ & 3186 & 4.4 \\
\hline Conv1 $^{2}$ & $1903^{\mathrm{b}}$ & $2138^{\mathrm{b}}$ & $2657^{\mathrm{c}}$ & $2278^{\mathrm{c}}$ & 2244 & 6.3 \\
\hline Conv $2^{3}$ & $2460^{\mathrm{a}}$ & $1268^{c}$ & $5111^{\mathrm{a}}$ & $2612^{b}$ & 2863 & 4.9 \\
\hline $\mathrm{CV}(\%)$ & 6.9 & 7.9 & 4.2 & 5.9 & & \\
\hline \multicolumn{7}{|c|}{ Botanical composition } \\
\hline \multicolumn{7}{|c|}{ Elephant grass $(\%)$} \\
\hline Org & $27.4^{\mathrm{b}}$ & $10.7^{\mathrm{b}}$ & $37.6^{\mathrm{b}}$ & $30.3^{b}$ & 26.5 & 11.5 \\
\hline Conv1 & $21.7^{\mathrm{c}}$ & $15.6^{\mathrm{b}}$ & $25.8^{\mathrm{c}}$ & $20.4^{\mathrm{c}}$ & 20.9 & 15.8 \\
\hline Conv2 & $86.0^{\mathrm{a}}$ & $93.0^{\mathrm{a}}$ & $94.1^{\mathrm{a}}$ & $91.2^{\mathrm{a}}$ & 91.1 & 2.8 \\
\hline CV $(\%)$ & 7.4 & 9.3 & 5.8 & 6.7 & & \\
\hline \multicolumn{7}{|c|}{ Ryegrass (\%) } \\
\hline Org & $27.3^{\mathrm{a}}$ & $21.8^{\mathrm{a}}$ & --- & --- & 24.5 & 12.2 \\
\hline Conv1 & $32.4^{\mathrm{a}}$ & $10.7^{\mathrm{b}}$ & --- & --- & 21.5 & 15.7 \\
\hline CV $(\%)$ & 12.2 & 15.7 & & & & \\
\hline \multicolumn{7}{|c|}{ Other warm grasses $(\%)$} \\
\hline Org & 25.8 & 44.9 & 39.7 & 46.7 & $39.7^{\mathrm{b}}$ & 7.1 \\
\hline Conv1 & 27.5 & 49.2 & 53.5 & 59.5 & $46.9^{\mathrm{a}}$ & 8.5 \\
\hline $\mathrm{CV}(\%)$ & 20.9 & 11.2 & 8.7 & 8.8 & & \\
\hline \multicolumn{7}{|c|}{ Other species $(\%)$} \\
\hline Org & 5.4 & 5.6 & 6.1 & 10.5 & 6.2 & 21.0 \\
\hline Conv1 & 7.1 & 4.1 & 7.1 & 10.0 & 7.1 & 24.3 \\
\hline CV $(\%)$ & 28.9 & 26.1 & 18.4 & 15.8 & & \\
\hline \multicolumn{7}{|c|}{ Dead material (\%) } \\
\hline Org & $14.8^{\mathrm{a}}$ & $16.9^{\mathrm{b}}$ & $16.5^{\mathrm{a}}$ & $12.4^{\mathrm{a}}$ & 15.1 & 8.7 \\
\hline Conv1 & $13.2^{\mathrm{a}}$ & $20.4^{\mathrm{a}}$ & $13.6^{\mathrm{a}}$ & $10.1^{\mathrm{a}}$ & 14.3 & 10.5 \\
\hline Conv2 & $13.9^{\mathrm{a}}$ & $5.1^{\mathrm{c}}$ & $5.0^{\mathrm{b}}$ & $8.8^{\mathrm{a}}$ & 8.2 & 11.3 \\
\hline CV $(\%)$ & 15.2 & 11.3 & 12.9 & 15.1 & & \\
\hline \multicolumn{7}{|c|}{ Relation leaf blade: stem + sheath elephant grass } \\
\hline Org & 1.3 & 16.6 & 3.0 & 2.7 & $5.9^{\mathrm{b}}$ & 7.2 \\
\hline Conv1 & 1.4 & 18.2 & 3.2 & 3.1 & $6.5^{\mathrm{b}}$ & 7.8 \\
\hline Conv2 & 1.6 & 22.7 & 3.5 & 3.3 & $7.7^{\mathrm{a}}$ & 6.4 \\
\hline $\mathrm{CV}(\%)$ & 5.0 & 5.4 & 3.8 & 11.3 & & \\
\hline
\end{tabular}

${ }^{1}$ Organic production system, with mixed pastures. ${ }^{2}$ Conventional production system, with mixed pastures. ${ }^{3}$ Conventional production system, with elephant grass cultivated alone. Different letters in the column differ by Student's $t$ test $(p \leq 0.05)$. DM=dry matter. $\mathrm{CV}=$ coefficient of variation. 
regard to pasture with organic production, with greater participation of elephant grass.

With relation regard to the ratio leaf blade: stem + sheath elephant grass, rates were high during spring. They averaged higher $(\mathrm{p} \leq 0.05)$ for pasture with an elephant grass alone, perhaps due to closeness with tufts, since this implied a greater participation of leaf blades in the plants' upper stratum.

To post-grazing herbage mass (Table II) rates reveal a low association with pre-grazing herbage mass, mainly due to the greater preference of cows to elephant grass and ryegrass when compared to tropical spontaneous-growth species (Azevedo Junior et al. 2012).

There was an increase in the participation of dead material due to animal trampling. Since rates for leaf blade: stem + sheath elephant grass were similar, the biomass of leaf blades provided adequate intake. Even during the winter, the percentage of leaf blades in the residual forage mass was close to $50 \%$ and thus sufficient for the plants' recovery (Rodolfo et al. 2014). In fact, it provided a new grazing in about 33 days (De Bem et al. 2015). There was no difference $(p \leq 0.05)$ for daily herbage accumulation during the winter for the pasture's productive variables (Table III). Result was due to high participation rate of elephant grass during this season (Table I) since it is tropical species. Mild weather conditions in the winter contributed towards such a performance with high yield participation when compared to response of the elephant grass in normal climate conditions (Steinwandter et al. 2009). The performance of elephant grass provided conditions so that the same number of grazing events could be undertaken.

In the other seasons, the forage accumulation rate was predominant in the conventional production system with singular elephant grass. Results were due to the yield forage's greater production potential with regard to the other species in systems formed by mixed pastures. Accumulation rates obtained during the summer and autumn are similar to those in the same region, between January and March, featuring cv. Taiwan elephant grass under cultivated alone and fertilized with $90 \mathrm{~kg} \mathrm{~N} \mathrm{ha}^{-1}$ (Míssio et al. 2006).

The participation of elephant grass in all seasons implied higher $(p \leq 0.05)$ forage yield for the conventional production system with elephant grass singular cultivation. Lower rates forage yield were detected in the region of Lages, SC, Brazil. During the first assessment year, under monoculture, among January and May, mean productions featured between 12 and $14 \mathrm{t} \mathrm{DM} \mathrm{ha}^{-1}$ in elephant grass cultivars (Dall'agnol et al. 2005). In the case of mixed pasture, similarity existed during the spring, whereas higher rates occurred in organic production systems during the other seasons. This condition was attributed to a better response to organic fertilization due to the gradual release of macro- and micro-nutrients for soil solution, proportional to the chemical fertilization (Menezes et al. 2004). It should be underscored that, in these systems, there was less variability in herbage yield between the seasons. There was a greater $(\mathrm{p} \leq 0.05)$ production in the winter and in the autumn within the mixed organic production system than to the conventional production system. In fact, there was less availability of forage during these seasons, not only in subtropical but also in tropical climates.

The system's effect $(p \leq 0.05)$ on grazing efficiency occurred in three out of the four seasons of the year, with lower rates for mixed systems, perhaps due to a smaller preference for spontaneous-growth species by the animals. Mean rate of grazing efficiency in these systems reached $38.7 \%$. The highest grazing efficiency in elephant grass cultivate alone pasture has been associated with the ratio leaf blade: stem + sheath elephant grass and also to greater stocking rate $(r=0.83$; $\mathrm{p}=<0.0001$ ); the grazing efficiency rates in the summer and autumn, albeit high, in these system 
TABLE II

Post-grazing herbage mass and botanic composition of pasture in three forage systems (FS). Santa Maria, Brazil, $2015-2016$.

\begin{tabular}{|c|c|c|c|c|c|c|}
\hline \multirow{2}{*}{ FS } & \multicolumn{4}{|c|}{ Season } & \multirow{2}{*}{ Mean } & \multirow{2}{*}{ CV $(\%)$} \\
\hline & Winter & Spring & Summer & Autumn & & \\
\hline \multicolumn{7}{|c|}{ Pasture forage mass $(\mathrm{kg} \mathrm{DM} \mathrm{ha-1})$} \\
\hline $\operatorname{Org} 1^{1}$ & $1513^{\mathrm{a}}$ & $1997^{\mathrm{a}}$ & $1841^{\mathrm{a}}$ & $2089^{\mathrm{a}}$ & 1860 & 6.4 \\
\hline Conv1 $1^{2}$ & $1248^{\mathrm{a}}$ & $1456^{\mathrm{b}}$ & $1323^{\mathrm{b}}$ & $1577^{\mathrm{b}}$ & 1401 & 8.5 \\
\hline Conv $2^{3}$ & $1554^{\mathrm{a}}$ & $513^{\mathrm{c}}$ & $885^{\mathrm{c}}$ & $959^{\mathrm{c}}$ & 978 & 12.2 \\
\hline CV $(\%)$ & 9.9 & 6.2 & 5.3 & 7.9 & & \\
\hline \multicolumn{7}{|c|}{ Botanical composition } \\
\hline \multicolumn{7}{|c|}{ Elephant grass (\%) } \\
\hline Org & $21.7^{\mathrm{b}}$ & $5.9^{\mathrm{b}}$ & $17.9^{\mathrm{b}}$ & $15.1^{\mathrm{b}}$ & 15.1 & 8.6 \\
\hline Conv1 & $13.9^{\mathrm{c}}$ & $10.2^{\mathrm{b}}$ & $11.9^{\mathrm{c}}$ & $7.1^{\mathrm{c}}$ & 10.7 & 11.6 \\
\hline Conv2 & $75.9^{\mathrm{a}}$ & $97.5^{\mathrm{a}}$ & $85.4^{\mathrm{a}}$ & $87.3^{\mathrm{a}}$ & 86.5 & 4.9 \\
\hline CV $(\%)$ & 6.8 & 6.6 & 3.4 & 14.3 & & \\
\hline \multicolumn{7}{|c|}{ Ryegrass (\%) } \\
\hline Org & 18.4 & 15.3 & --- & --- & $16.8^{\mathrm{a}}$ & 8.4 \\
\hline Conv1 & 16.6 & 9.2 & --- & --- & $12.9^{\mathrm{b}}$ & 11.1 \\
\hline CV $(\%)$ & 9.3 & 9.9 & & & & \\
\hline \multicolumn{7}{|c|}{ Other warm grasses $(\%)$} \\
\hline Org & $28.8^{\mathrm{a}}$ & $51.2^{\mathrm{a}}$ & $54.3^{\mathrm{b}}$ & $56.9^{\mathrm{b}}$ & 47.8 & 8.9 \\
\hline Conv1 & $30.1^{\mathrm{a}}$ & $50.0^{\mathrm{a}}$ & $61.5^{\mathrm{a}}$ & $63.1^{\mathrm{a}}$ & 51.2 & 10.6 \\
\hline CV $(\%)$ & 6.2 & 10.1 & 8.5 & 16.0 & & \\
\hline \multicolumn{7}{|c|}{ Other species $(\%)$} \\
\hline Org & 3.4 & 8.5 & 10.7 & 15.1 & 9.4 & 31.6 \\
\hline Conv1 & 3.5 & 8.4 & 13.9 & 16.6 & 10.6 & 37.6 \\
\hline $\mathrm{CV}(\%)$ & 56.1 & 39.0 & 21.7 & 21.8 & & \\
\hline \multicolumn{7}{|c|}{ Dead material (\%) } \\
\hline Org & $27.4^{\mathrm{b}}$ & $18.7^{\mathrm{b}}$ & $17.0^{\mathrm{b}}$ & $12.9^{\mathrm{a}}$ & 19.0 & 8.6 \\
\hline Conv1 & $35.6^{\mathrm{a}}$ & $22.2^{\mathrm{a}}$ & $14.9^{\mathrm{a}}$ & $13.0^{\mathrm{a}}$ & 21.4 & 9.3 \\
\hline Conv2 & $24.1^{\mathrm{b}}$ & $23.5^{\mathrm{a}}$ & $14.5^{\mathrm{a}}$ & $12.6^{\mathrm{a}}$ & 18.8 & 8.3 \\
\hline CV $(\%)$ & 11.2 & 11.2 & 14.4 & 14.5 & & \\
\hline \multicolumn{7}{|c|}{ Relation leaf blade: stem + sheath elephant grass } \\
\hline Org & 0.4 & 4.5 & 2.1 & 1.5 & 2.1 & 12.2 \\
\hline Conv1 & 0.6 & 4.0 & 1.4 & 1.1 & 1.8 & 11.4 \\
\hline Conv2 & 0.7 & 5.4 & 2.2 & 1.0 & 2.3 & 11.7 \\
\hline CV $(\%)$ & 8.4 & 14.2 & 5.1 & 13.1 & & \\
\hline
\end{tabular}

${ }^{1}$ Organic production system, with mixed pastures. ${ }^{2}$ Conventional production system, with mixed pastures. ${ }^{3}$ Conventional production system, with elephant grass cultivated alone. Different letters in the column differ by Student's t test $(\mathrm{p} \leq 0.05)$. DM=dry matter. $\mathrm{CV}=$ coefficient of variation. 
TABLE III

Forage productivity and animal response in three forage systems (FS). Santa Maria, Brazil, 2015-2016.

\begin{tabular}{|c|c|c|c|c|c|c|}
\hline \multirow{2}{*}{ FS } & \multicolumn{4}{|c|}{ Season } & \multirow{2}{*}{ Mean } & \multirow{2}{*}{ CV $(\%)$} \\
\hline & Winter & Spring & Summer & Autumn & & \\
\hline \multicolumn{7}{|c|}{ Herbage accumulation rate $\left(\mathrm{kg} \mathrm{ha}^{-1}\right.$ day $\left.^{-1}\right)$} \\
\hline $\operatorname{Org} 1^{1}$ & $27.8^{\mathrm{a}}$ & $18.4^{\mathrm{b}}$ & $83.5^{\mathrm{b}}$ & $37.3^{\mathrm{b}}$ & 41.8 & 4.9 \\
\hline Conv $^{2}$ & $18.7^{\mathrm{a}}$ & $26.7^{\mathrm{ab}}$ & $60.3^{c}$ & $21.4^{\mathrm{c}}$ & 31.8 & 5.5 \\
\hline Conv $2^{3}$ & $25.2^{\mathrm{a}}$ & $30.6^{\mathrm{a}}$ & $143.1^{\mathrm{a}}$ & $53.8^{\mathrm{a}}$ & 63.1 & 4.0 \\
\hline CV $(\%)$ & 7.0 & 6.9 & 3.5 & 5.7 & & \\
\hline \multicolumn{7}{|c|}{ Forage yield $\left(\mathrm{kg} \mathrm{ha}^{-1}\right)$} \\
\hline Org & $2363^{\mathrm{a}}$ & $2061^{\mathrm{bc}}$ & $6930^{\mathrm{b}}$ & $1194^{\mathrm{b}}$ & 3137 & 3.9 \\
\hline Conv1 & $1590^{\mathrm{b}}$ & $2990^{\mathrm{b}}$ & $5005^{\mathrm{c}}$ & $685^{\mathrm{c}}$ & 2567 & 4.6 \\
\hline Conv2 & $2142^{\mathrm{ab}}$ & $3427^{\mathrm{a}}$ & $11877^{\mathrm{a}}$ & $1722^{\mathrm{a}}$ & 4792 & 3.3 \\
\hline $\mathrm{CV}(\%)$ & 5.2 & 5.2 & 2.7 & 6.9 & & \\
\hline \multicolumn{7}{|c|}{ Grazing efficiency (\%) } \\
\hline Org & $44.2^{\mathrm{a}}$ & $28.1^{\mathrm{b}}$ & $52.5^{\mathrm{b}}$ & $38.1^{\mathrm{b}}$ & 40.7 & 8.3 \\
\hline Conv1 & $34.4^{\mathrm{b}}$ & $31.9^{\mathrm{b}}$ & $50.2^{\mathrm{b}}$ & $30.7^{\mathrm{b}}$ & 36.8 & 8.8 \\
\hline Conv2 & $36.8^{\mathrm{b}}$ & $59.4^{\mathrm{a}}$ & $82.7^{\mathrm{a}}$ & $63.3^{\mathrm{a}}$ & 60.5 & 5.6 \\
\hline $\mathrm{CV}(\%)$ & 9.5 & 12.2 & 2.2 & 10.3 & & \\
\hline \multicolumn{7}{|c|}{ Apparent forage intake (\% BW) } \\
\hline Org & 2.1 & 2.0 & 2.5 & 3.2 & 2.5 & 5.7 \\
\hline Conv1 & 2.3 & 2.5 & 2.9 & 2.6 & 2.6 & 5.5 \\
\hline Conv2 & 2.8 & 1.8 & 3.5 & 2.5 & 2.7 & 5.4 \\
\hline $\mathrm{CV}(\%)$ & 5.7 & 7.2 & 2.6 & 8.7 & & \\
\hline \multicolumn{7}{|c|}{ Stocking rate $\left(\mathrm{AU} \mathrm{ha}^{-1} \mathrm{dia}^{-1}\right)$} \\
\hline Org & $1.4^{\mathrm{a}}$ & $2.1^{\mathrm{b}}$ & $6.8^{\mathrm{b}}$ & $2.9^{\mathrm{b}}$ & 3.3 & 4.5 \\
\hline Conv1 & $0.7^{\mathrm{b}}$ & $2.0^{\mathrm{b}}$ & $3.8^{\mathrm{c}}$ & $1.9^{\mathrm{c}}$ & 2.1 & 5.7 \\
\hline Conv2 & $0.8^{\mathrm{b}}$ & $3.2^{\mathrm{a}}$ & $9.5^{\mathrm{a}}$ & $4.4^{\mathrm{a}}$ & 4.5 & 4.0 \\
\hline $\mathrm{CV}(\%)$ & 5.6 & 9.7 & 2.4 & 3.7 & & \\
\hline
\end{tabular}

${ }^{1}$ Organic production system, with mixed pastures. ${ }^{2}$ Conventional production system, with mixed pastures. ${ }^{3}$ Conventional production system, with elephant grass cultivated alone. Different letters in the column differ by Student's $t$ test ( $\mathrm{p} \leq 0.05$ ). BW=body weight. $\mathrm{AU}=$ animal unit, $450 \mathrm{~kg}$. $\mathrm{CV}=$ coefficient of variation. Grazing cycles: winter (1) - from sowing of ryegrass, $15 / 05$, to $1^{\text {st }}$ grazing, 09/08 (85 days); spring (2) - end of $1^{\text {st }}, 17 / 08$, to start of $3^{\text {rd }}$ grazing, 08/12 (112 days); summer ( 3 ) - end of $3^{\text {rd }}$ grazing, $17 / 12$, to start of $6^{\text {th }}$ grazing, 09/03 (83 days); autumn (1) - end of $6^{\text {th }}$ grazing, $16 / 03$, to the start of $7^{\text {th }}$ grazing cycle, 17/04 (32 days).

were adequate, even though they could constraint forage intake (Delagarde et al. 2001).

There was no difference in forge intake between the forage systems. Total animal intake is 3.5\% when mean rate $2.6 \%$ (pasture) is added to feed supplementation $(0.9 \%)$. The former percentage is above that expected for lactating cows according to body weight and milk yield (NRC 2001).

There was a difference with regard to stocking rates between the systems. Pasture at organic production was higher during the winter when compared to the other seasons due to a 
greater production of ryegrass. This amount also occurred in conventional pasture with elephant grass cultivate alone during the other seasons. It should be underscored that, between the similarly established mixed systems, higher results occurred in the organic system $(r=0.76 ; p=0.0048)$ due to a greater participation of elephant grass in pasture composition (Table I).

In the case of variables for the nutritive value of elephant grass forage mass (Table IV), there was no interaction between seasons and systems, or rather, the period did not affect results. Organic matter rates for elephant grass were lower than those for the species when associated with forage groundnut or red clover, with mean $89 \%$ (Diehl et al. 2014). Perhaps due to organic fertilization, the system affected $\mathrm{CP}$ rate, with a greater rate $(\mathrm{p} \leq 0.05)$ in forage under organic production. The application of manure raised the rate of organic matter in the soil and improved the chemical composition of elephant grass (Oliveira et al. 2013). It must be underscored that during the winter the $\mathrm{CP}$ tenor of elephant grass is low, probably due to mild weather and, thus, pasture growth. CP rates in a normal climate tend to be higher in the winter, already verified in the same region, with $17.7 \%$ and $13.7 \%$ for winter and summer, respectively (Olivo et al. 2007). Above results are due to a greater development of the plant in hotter periods, with a subsequent rise in rates for cell wall, lignin, fiber and cellulose which usually have an inverse relationship with CP concentration (Macedo Júnior et al. 2007).

Mean estimates ISDOM and TDN reached $74.0 \%$ and $61.4 \%$ respectively, or rather, close to those for elephant grass with different forage legumes (Diehl et al. 2014). The similarity of the components of the elephant grass's nutritive value between the seasons may be associated with meteorological conditions in which elephant grass grew throughout the whole year (Table I). Normal climatic conditions affect the nutritive value variables of elephant grass (Meinerz et al. 2008).
In the case of variables of the nutritive value of forage in the in-between rows, there was an interaction between seasons and systems for organic matter and CP rates. During the summer, highest rate $(p \leq 0.05)$ for organic matter in the conventional system is due to a lower participation of the pasture's dead material (Tables I and II). Higher rates in CP during the winter and in the spring are due to a greater participation of ryegrass (Table I) and a smaller participation of dead material (Table II). High rates during the summer indicate that spontaneous-growth species, such as Paspalum conjugatum, Paspalum urvillei Steud., Setaria spp. and Dichanthelium spp. have significant $\mathrm{CP}$ concentration. However, CP rates decrease during the autumn and indicate that species are more sensitive to fall in temperature when compared to elephant grass under analysis (Tables III and IV). There was neither interaction nor system effect on ISDOM and TDN. When the variables of forage's nutritive value in the in-between rows are taken into account, rates are high (Diehl et al. 2014), even though there is a greater variability between the seasons, when compared to elephant grass.

The extraction/ export forage yield by cows (Table $V)$ had a higher rate $(p \leq 0.05)$ in the conventional system with elephant grass cultivate alone, followed by the organic system, demonstrating a relationship $(\mathrm{r}=0.99 ; \mathrm{p}=<0.0001)$ with the herbage yield. To extraction/ export of $\mathrm{CP}$, there is equilibrium between the conventional system under monoculture with elephant grass and the organic system. Similarity in three out of the four seasons in these systems demonstrated that a greater performance in CP export was registered. Similar results were obtained for the extraction/ export of $\mathrm{N}$, especially during the winter and spring. There was a relationship $(r=0.97 ; p=<0.0001)$ with regard to energy between the export of dry matter and TDN, due to the similarity in the digestibility (Table IV) of forage mass between pastures. The energy removal was greater $(\mathrm{p} \leq 0.05)$ compared with conventional system with mixed pastures. 
TABLE IV

Nutritive value of elephant grass and the forage in the in-between rows, in three forage systems (FS). Santa Maria, Brazil, $2015-2016$.

\begin{tabular}{|c|c|c|c|c|c|c|}
\hline \multirow{2}{*}{ FS } & \multicolumn{4}{|c|}{ Season } & \multirow{2}{*}{ Mean } & \multirow{2}{*}{$\begin{array}{l}\text { CV } \\
(\%)\end{array}$} \\
\hline & Winter & Spring & Summer & Autumn & & \\
\hline \multicolumn{7}{|c|}{ Elephant grass } \\
\hline \multicolumn{7}{|c|}{ Organic matter $(\%)$} \\
\hline $\operatorname{Org} 1^{1}$ & 81.8 & 80.8 & 84.5 & 81.7 & 82.2 & 0.6 \\
\hline Conv $^{2}$ & 82.6 & 82.1 & 84.4 & 81.4 & 82.6 & 0.6 \\
\hline Conv $2^{3}$ & 83.6 & 83.8 & 84.7 & 82.9 & 83.8 & 0.6 \\
\hline CV (\%) & 0.5 & 0.8 & 0.6 & 0.5 & & \\
\hline \multicolumn{7}{|c|}{ Crude protein $(\%)$} \\
\hline Org & 17.3 & 19.1 & 16.4 & 18.7 & $17.9^{\mathrm{a}}$ & 3.0 \\
\hline Conv1 & 14.3 & 14.4 & 16.5 & 16.6 & $15.4^{\mathrm{b}}$ & 3.5 \\
\hline Conv2 & 14.8 & 15.6 & 17.7 & 17.4 & $16.4^{\mathrm{b}}$ & 3.3 \\
\hline $\mathrm{CV}(\%)$ & 1.6 & 4.2 & 5.2 & 2.5 & & \\
\hline \multicolumn{7}{|c|}{ In situ digestibility of organic matter $(\%)$} \\
\hline Org & 71.0 & 76.3 & 74.5 & 75.6 & 74.3 & 3.1 \\
\hline Conv1 & 75.6 & 76.1 & 76.2 & 69.6 & 74.4 & 3.1 \\
\hline Conv2 & 73.9 & 75.3 & 73.4 & 71.3 & 73.5 & 3.1 \\
\hline $\mathrm{CV}(\%)$ & 1.6 & 3.0 & 2.4 & 3.8 & & \\
\hline \multicolumn{7}{|c|}{ Total digestible nutrients $(\%)$} \\
\hline Org & 58.1 & 61.6 & 62.9 & 61.8 & 61.1 & 2.5 \\
\hline Conv1 & 62.5 & 62.5 & 64.3 & 56.6 & 61.5 & 2.5 \\
\hline Conv2 & 61.8 & 63.2 & 62.2 & 59.1 & 61.6 & 2.5 \\
\hline $\mathrm{CV}(\%)$ & 3.0 & 2.9 & 2.8 & 3.0 & & \\
\hline \multicolumn{7}{|c|}{ Forage in the in-between rows } \\
\hline \multicolumn{7}{|c|}{ Organic matter $(\%)$} \\
\hline Org & $84.1^{\mathrm{a}}$ & $86.0^{\mathrm{a}}$ & $84.0^{\mathrm{b}}$ & $83.8^{\mathrm{a}}$ & 84.5 & 0.3 \\
\hline Conv1 & $85.3^{\mathrm{a}}$ & $86.5^{\mathrm{a}}$ & $86.1^{\mathrm{a}}$ & $84.0^{\mathrm{a}}$ & 85.5 & 0.3 \\
\hline $\mathrm{CV}(\%)$ & 0.5 & 0.8 & 0.1 & 0.3 & & \\
\hline \multicolumn{7}{|c|}{ Crude protein $(\%)$} \\
\hline Org & $14.9^{\mathrm{a}}$ & $13.7^{\mathrm{a}}$ & $22.6^{\mathrm{a}}$ & $13.1^{\mathrm{a}}$ & 16.0 & 2.9 \\
\hline Conv1 & $11.6^{\mathrm{b}}$ & $10.7^{\mathrm{b}}$ & $20.5^{\mathrm{a}}$ & $12.1^{\mathrm{a}}$ & 13.7 & 3.1 \\
\hline CV $(\%)$ & 4.9 & 5.2 & 2.9 & 5.1 & & \\
\hline \multicolumn{7}{|c|}{ In situ digestibility of organic matter (\%) } \\
\hline Org & 77.4 & 59.2 & 71.4 & 61.5 & 67.4 & 2.5 \\
\hline Conv1 & 73.3 & 61.5 & 66.6 & 62.4 & 66.0 & 2.5 \\
\hline CV $(\%)$ & 3.1 & 3.9 & 3.4 & 3.8 & & \\
\hline \multicolumn{7}{|c|}{ Total digestible nutrients $(\%)$} \\
\hline Org & 65.1 & 50.9 & 60.0 & 51.6 & 56.9 & 2.6 \\
\hline Conv1 & 62.5 & 53.3 & 57.4 & 52.5 & 56.4 & 2.6 \\
\hline CV (\%) & 3.3 & 4.1 & 3.6 & 4.1 & & \\
\hline
\end{tabular}

${ }^{1}$ Organic production system, with mixed pastures. ${ }^{2}$ Conventional production system, with mixed pastures. ${ }^{3}$ Conventional production system, with elephant grass cultivated alone. Different letters in the column differ by Student's $t$ test $(p \leq 0.05)$. CV $=$ coefficient of variation. 
TABLE V

Extraction/ export forage variables and nutrient $(\mathrm{N})$ in three forage systems (FS). Santa Maria, Brazil, 2015-2016.

\begin{tabular}{|c|c|c|c|c|c|c|}
\hline \multirow{2}{*}{ FS } & \multicolumn{4}{|c|}{ Season } & \multirow{2}{*}{ Total } & \multirow{2}{*}{ CV $(\%)$} \\
\hline & Winter & Spring & Summer & Autumn & & \\
\hline \multicolumn{7}{|c|}{ Forage yield $\left(\mathrm{kg} \mathrm{DM} \mathrm{ha}^{-1}\right)$} \\
\hline $\operatorname{Org}^{1}$ & $1201.7^{\mathrm{a}}$ & $777.7^{\mathrm{a}}$ & $1952.9^{\mathrm{b}}$ & $1284.8^{\mathrm{b}}$ & $5216.3^{b}$ & 9.0 \\
\hline Conv1 $^{2}$ & $654.9^{\mathrm{b}}$ & $703.5^{\mathrm{a}}$ & $1281.5^{\mathrm{c}}$ & $700.8^{\mathrm{c}}$ & $3340.3^{\mathrm{c}}$ & 14.1 \\
\hline Conv $2^{3}$ & $906.5^{\mathrm{c}}$ & $716.7^{\mathrm{a}}$ & $4188.2^{\mathrm{a}}$ & $1653.7^{\mathrm{a}}$ & $7465.0^{\mathrm{a}}$ & 6.3 \\
\hline $\mathrm{CV}(\%)$ & 14.7 & 18.5 & 5.5 & 11.2 & & \\
\hline \multicolumn{7}{|c|}{ Nitrogen $\left(\mathrm{kg} \mathrm{DM} \mathrm{ha}{ }^{-1}\right)$} \\
\hline Org & $30.8^{\mathrm{a}}$ & $18.8^{\mathrm{a}}$ & $56.8^{\mathrm{b}}$ & $33.9^{\mathrm{b}}$ & $140.3^{\mathrm{b}}$ & 9.3 \\
\hline Conv1 & $13.0^{\mathrm{c}}$ & $13.7^{\mathrm{b}}$ & $42.6^{\mathrm{c}}$ & $16.8^{\mathrm{c}}$ & $86.1^{\mathrm{c}}$ & 15.1 \\
\hline Conv2 & $20.7^{\mathrm{b}}$ & $16.6^{\mathrm{ab}}$ & $111.2^{\mathrm{a}}$ & $43.9^{\mathrm{a}}$ & $192.4^{\mathrm{a}}$ & 6.7 \\
\hline CV $(\%)$ & 17.9 & 22.8 & 5.3 & 11.8 & & \\
\hline \multicolumn{7}{|c|}{ Crude protein $(\mathrm{kg} \mathrm{DM} \mathrm{ha-1})$} \\
\hline Org & $189.3^{\mathrm{a}}$ & $117.7^{\mathrm{a}}$ & $352.4^{\mathrm{b}}$ & $208.7^{\mathrm{a}}$ & $868.4^{\mathrm{b}}$ & 9.3 \\
\hline Conv1 & $81.7^{\mathrm{b}}$ & $85.7^{\mathrm{b}}$ & $262.9^{\mathrm{c}}$ & $105.2^{\mathrm{b}}$ & $534.7^{\mathrm{c}}$ & 15.1 \\
\hline Conv2 & $129.2^{\mathrm{a}}$ & $102.9^{\mathrm{a}}$ & $693.9^{\mathrm{a}}$ & $274.4^{\mathrm{a}}$ & $1200.5^{\mathrm{a}}$ & 6.7 \\
\hline $\mathrm{CV}(\%)$ & 17.5 & $22.8 \mathrm{a}$ & 5.3 & 11.9 & & \\
\hline \multicolumn{7}{|c|}{ Total digestible nutrients $(\mathrm{kg} \mathrm{DM} \mathrm{ha-1})$} \\
\hline Org & $748.5^{\mathrm{a}}$ & $419.5^{\mathrm{a}}$ & $1218.8^{b}$ & $741.8^{\mathrm{b}}$ & $3128.7^{b}$ & 8.6 \\
\hline Conv1 & $407.5^{\mathrm{c}}$ & $394.6^{\mathrm{a}}$ & $765.8^{\mathrm{c}}$ & $397.2^{\mathrm{c}}$ & $1963.7^{\mathrm{c}}$ & 13.7 \\
\hline Conv2 & $566.4^{\mathrm{b}}$ & $447.4^{\mathrm{a}}$ & $2693.1^{\mathrm{a}}$ & $937.2^{\mathrm{a}}$ & $4643.8^{\mathrm{a}}$ & 5.8 \\
\hline CV $(\%)$ & 13.5 & 18.5 & 4.9 & 11.4 & & \\
\hline
\end{tabular}

${ }^{1}$ Organic production system, with mixed pastures. ${ }^{2}$ Conventional production system, with mixed pastures. ${ }^{3}$ Conventional production system, with elephant grass cultivated alone. Different letters in the column differ by Student's $t$ test $(p \leq 0.05)$. CV=coefficient of variation. Different letters in the column differ by Student's t test $(\mathrm{p} \leq 0.05)$.

\section{CONCLUSIONS}

Elephant grass mixed with other species adapts itself in organic and in conventional production. Mixed pastures, in conventional and organic production, had a better forage distribution throughout the seasons and herbage yield was greater in elephant grass cultivated alone. To mixed pastures, better nutritive value and greater productivity was found in organic production system. The extraction/ export dry mater, N, CP and TDN was greater in elephant grass system cultivated alone. There is a better grazing efficiency and a higher forage yield, mainly in the summer, to elephant grass cultivated alone under conventional production system.

\section{AUTHOR CONTRIBUTIONS}

Gabriela Descovi Simonetti: Participated in all stages of the research, from the planning, execution, writing and revision of the manuscript. Clair Jorge Olivo: Advised and supervised the research, from the planning to the finalization of the manuscript. Daiane Cristine Seibt: followed the activities of data 
collection and analysis, contributing to the scientific construction of the manuscript, considering the reading and revision stages. Vinicius Felipe Bratz: followed the activities of field data collection and contributed to the scientific construction of the manuscript, considering the reading and revision stages. Julio Clemente Sauthier: followed the activities of field data collection and contributed to the scientific construction of the manuscript, considering the reading and review stages. Carine Beatriz Adams: followed the activities of data collection in the laboratory and contributed to the scientific construction of the manuscript, considering the steps of reading and review.

\section{REFERENCES}

AOAC - ASSOCIATION OF OFFICIAL ANALYTICAL CHEMISTS. 1995. Official methods of analysis, $12^{\text {nd }} \mathrm{ed}$., Washington: DC, $1141 \mathrm{p}$.

AZEVEDO JUNIOR RL, OLIVO CJ, DE BEM CM, AGUIRRE PF, QUATRIN MP, SANTOS MM, BRATZ VF AND HORST T. 2012. Forage mass and the nutritive value of pastures mixed with forage peanut and red clover. Rev Bras Zootec 41(4): 824-827.

BARBER WPB, ADAMSON AH AND ALTMAN JFB. 1984. New methods of feed evaluation. In: Haresign W and Cole DJA (Eds), Recent advances in animal nutrition. London: Butterworths, p. 161-176.

BURNS JC, POND KR AND FISHER DS. 1994. Measurement of forage intake. In: Fahey Jr et al. (Eds), Forage quality, evaluation, and utilization. Wisconsin: American Society of Agronomy, p. 494-532.

COMISSÃO DE QUÍMICA E FERTILIDADE DO SOLO - RS/SC. 2004. Manual de adubação e calagem para os estados do Rio Grande do Sul e Santa Catarina. Porto Alegre: SBCSN/RS, 400 p.

DALL'AGNOL M, SCHEFFER-BASSO SM, NASCIMENTO JAL, SILVEIRA CAM AND FISCHER RG. 2005. Produção de forragem de capim-elefante sob clima frio. Produção e seletividade animal. Rev Bras Zootec 34(2): 425-432.

DE BEM CM, OLIVO CJ, AGNOLIN CA, AGUIRRE PF, BRATZ VF, QUATRIN MP, RODRIGUESA, SIMONETTI GD, SANTOS FT AND ALESSIO V. 2015. Dinâmica e valor nutritivo da forragem de sistemas forrageiros submetidos à produção orgânica e convencional. Rev Bras Saúde Prod Anim 16(3): 513-522.
DELAGARDE R, PRACHE S, D'HOUR P AND PETIT M. 2001. Ingestion de l'herbe par les ruminants au pâturage. Fourrages 166(1): 189-212.

DERESZ F. 2001. Influência do Período de Descanso da Pastagem de Capim-Elefante na Produção de Leite de Vacas Mestiças Holandês x Zebu. Rev Bras Zootec 30(2): 461-469.

DIEHL MS, OLIVO CJ, AGNOLIN CA, BRATZ VF, DE BEM CM, AGUIRRE PF, GLIENKE CL, CORREA MR AND SERAFIM G. 2013. Productivity of grazing systems mixed forage legumes. Arq Bras Med Vet Zootec 65(5): 1527-1536.

DIEHL MS, OLIVO CJ, AGNOLIN CA, JUNIOR RLA, BRATZ VF AND SANTOS JC. 2014. Massa de forragem e valor nutritivo de capim elefante e espécies de crescimento espontâneo consorciadas com amendoim forrageiro ou trevo vermelho. Ciênc Rural 44(10): 1845-1852.

EUCLIDES VPB, MACEDO MCM AND OLIVEIRA MP. 1992. Avaliação de diferentes métodos de amostragens sob pastejo. Rev Bras Zootec 21(5): 691-702.

HODGSON J. 1979. Nomenclature and definitions in grazing studies. Grass and Forage Science 34(1): 11-18.

INMET - INSTITUTO NACIONAL DE METEOROLOGIA. 2016. Banco de dados meteorológicos para ensino e pesquisa. Dados mensais Estação Meteorológica de Santa Maria - Cód. A803, 2014-2015.

KUINCHTNER A AND BURIOL GA. 2001. Clima do Estado do Rio Grande do Sul segundo a classificação de Koppen e Thornthwaite. Disciplinarum Scientia 2(1): 171-182.

MACEDO JÚNIOR GL, ZANINE AM, BORGES I AND PÉREZ JRO. 2007. Qualidade da fibra para a dieta de ruminantes. Ciênc Animal 17(1): 7-17.

MEHREZ AZ AND ORSKOV ER. 1977. A study of the artificial fibre bag technique for determining the digestibility of feed in the rumen. Jour of Agric Scie 88(3): 645-650.

MEINERZ GR, OLIVO CJ, ZIECH MF, AGNOLIN CA, DULLIUS AP AND MORAES RS. 2008. Composição nutricional de pastagens de capim-elefante submetido a duas estratégias de manejo em pastejo. Acta Scientiarum Anim Scie 30(4): 379-385.

MENEZES JFS, ANDRADE CLT, ALVARENGA RC, KONZEN EA AND PIMENTA FF. 2004. Cama de frango na agricultura: perspectivas e viabilidade técnico e econômica. Boletim Técnico, 3, Rio Verde: FESURV, 28 p.

MÍSSIO RL, BRONDANI IL AND MENEZES LFG. 2006. Mass of leaf lamina in the productive and qualitative characteristics of Elephantgrass "Pennisetum purpureum Schum." (cv. Taiwan) pasture and animal performance. Ciênc Rural 36(4): 1243-1248.

NRC - NATIONAL RESEARCH COUNCIL. 2001. Nutrient requeriments of dairy cattle, $7^{\text {th }}$ ed., Washinton: DC, $381 \mathrm{p}$. 
OLIVEIRA TS. 2013. Qualidade química do solo e características produtivas do capim-elefante submetido à adubação química e orgânica. Rev Bras Agropec Sust 1(3): 99-104.

OLIVEIRA TS, PEREIRA JC, REIS CS, QUEIROZ AC, CECON PR AND GOMES ST. 2011. Composição químico-bromatológica do capim elefante submetido à adubação química e orgânica. Rev Bras Saúde Prod Anim 12(1): 32-42.

OLIVO CJ, CHARÃO PS, PEREIRA LET, ZIECH MF, MEINERZ G AND TYSKA D. 2007. Produtividade e valor nutritivo de pasto de capim-elefante manejado sob princípios agroecológicos. Rev Bras Zootec 36(6): 1729 1735.

OLIVO CJ, DIEHL MS, AGNOLIN CA, BRATZ VF, AGUIRRE PF AND SAUTER CP. 2017. Forage systems mixed with forage legumes grazed by lactating cows. Acta Scientiarum Anim Sci 39(1): 19-26.

OLIVO CJ, SOBCZAK MF, CHARÃO PS, ZIECH MF, ROSSAROLLA EMA, UBERTY LF AND SCHWENDLER SE. 2006. Evaluation of an elephant grass pasture, managed under agroecology principles, during the summer period. Livestock Research for Rural Development 18(2): 1-10.

PEGORARO RF, MISTURA C, WENDLING B, FONSECA DM AND FAGUNDES JL. 2009. Manejo da água e do nitrogênio em cultivo de capim-elefante. Ciênc Agrotec 33(2): 461-467.
RODOLFO GR, SCHMITT D, DIAS KM AND SBRISSIA AF. 2014. Levels of defoliation and regrowth dynamics in elephant grass swards. Ciênc Rural 45(7): 1299-1304.

SAS INSTITUTE. 2016. SAS User's guide: statistics. Version 8.2, Cary: Statistical Analysis System Institute, 1686 p.

SEIBT DC, OLIVO CJ, ALESSIO V, SILVA AR, QUATRIN MP AND ANJOS ANA. 2018. Forage production in mixed grazing systems of elephant grass with arrowleaf clover or forage peanut. Rev Ceres 65(2): 174-180.

SILVA DJ AND QUEIROZ AC. 2006. Análise de alimentos: métodos químicos e biológicos, Minas Gerais: UFV, 235 p.

SMITH DW. 2014. Soil Survey Staff: Keys to Soil Taxonomy, Washington: Natural Resources Conservation Service, 372 p.

SOARES JPG, BERCHIELLI TT, AROEIRA LJM, DERESZ F AND VERNEQUE RS. 2004. Estimativas de consumo do capim-elefante (Pennisetum purpureum Schum.), fornecido picado para vacas lactantes utilizando a técnica do óxido crômico. Rev Bras Zootec 33(3): 811-820.

STEINWANDTER E, OLIVO CJ, SANTOS JC, ARAÚJO TLR, AGUIRRE PF AND DIEHL MS. 2009. Produção de forragem consorciadas com diferentes leguminosas sob pastejo rotacionado. Acta Scientiarum Anim Scie 31(2): 31-137.

VOLTOLINI TV, SANTOS FAP, MARTINEZ JC, CLARINDO RL, PENATI MA AND IMAIZUMI H. 2010. Características produtivas e qualitativas do capim-elefante pastejado em intervalo fixo ou variável de acordo com a interceptação da radiação fotossinteticamente ativa. Rev Bras Zootec 39(5): 1002-1010. 